\title{
Fishery and geospatial mapping of pelagic elasmobranchs from mechanised gillnetters of Tharuvaikulam, Thoothukudi, south-east coast of India
}

\author{
P. P. MANOJKUMAR, L. RANJITH AND K. P. KANTHAN \\ Tuticorin Research Centre of ICAR-Central Marine Fisheries Research Institute, Thoothukudi - 628 001, Tamil Nadu, India \\ e-mail:manojppin@yahoo.com
}

\begin{abstract}
The pelagic elasmobranchs fishery of multiday gillnetters (MGNs) of Tharuvaikulam, Thoothukudi was studied during 2015-2016. Fishery data revealed that MGNs targeting scombrids and other large pelagic fishes also contribute to the pelagic elasmobranch landings accounting for 7.67 and 5.3\% of total elasmobranchs landed at Tharuvaikulam during 2015 and 2016 respectively. The catch per unit effort (CPUE) varied from 2.09 to $175 \mathrm{~kg}$ (2015) and 13 to $124.95 \mathrm{~kg}$ (2016). In total, 15 species of pelagic elasmobranchs were recorded during the study period, which includes 7 species of sharks and 8 species of rays. The pelagic elasmobranchs fishery of Tharuvaikulam depends mainly on two species namely bigeye thresher, Alopias superciliosus and spinetail devilray, Mobula japanica. The geospatial mapping revealed that fishing grounds of MGNs was between $77^{\circ}$ to $80^{\circ} \mathrm{E}$ longitudes and $7^{\circ}$ to $9^{\circ} \mathrm{N}$ latitudes with depth ranging from 50 to $200 \mathrm{~m}$. The persistence of fishing grounds of pelagic elasmobranchs was identified by classifying the fishing areas of Gulf of Mannar Biosphere Reserve (GOMBR) into seven zones. The results showed that more fishing happens in Zone 4, off Thoothukudi between $78^{\circ}$ to $79^{\circ} \mathrm{E}$ and $8^{\circ}$ to $9^{\circ} \mathrm{N}$ followed by Zone 7 , off Kanyakumari between $77^{\circ}$ to $78^{\circ} \mathrm{E}$ and $7^{\circ}$ to $8^{\circ} \mathrm{N}$. Seasonal analysis revealed that along with the targeted groups, the CPUE of pelagic elasmobranchs was higher during the pre-monsoon season. The present paper illustrates the zonal distribution of pelagic elasmobranchs in the fishing grounds of MGNs in GOMBR, along the south-east coast of India and the results of the study would serve as baseline information for formulating future management plans.
\end{abstract}

Keywords: Distribution, Elasmobranchs, Gillnet fishery, GIS, Gulf of Mannar

\section{Introduction}

Elasmobranchs form one of the largest demersal marine fishery resources of India and are exploited by different types of gears. Elasmobranch production during 2014 was 47, $242 \mathrm{t}$ with trawl nets accounting for $46.1 \%$, gillnets $34.2 \%$, hooks and lines $4.6 \%$, dol nets $3.1 \%$, and seines and bag nets together contributing $0.2 \%$. Elasmobranch catch showed an increase from 1961 to 2005 and in 2015, elasmobranch landings of India was 52, 434.5 t (Mohanraj et al., 2009; CMFRI, 2016), with mechanised sector contributing $77.7 \%$, while motorised and non-mechanised sectors contributing 21.7 and $0.6 \%$ respectively. In Tamil Nadu, the major fishing gears contributing to elasmobranch landings were trawlers and gillnetters (CMFRI, 2015). The elasmobranch landings in Tamil Nadu fluctuated between $1985(8,607 \mathrm{t})$ to 2015 $(13,854 \mathrm{t})$ with an average of $13,854 \mathrm{t}$ and peaked at 26, $985 \mathrm{t}$ during 1997 (Raje et al., 2002; CMFRI, 2016). In 2015, sharks contributed only $3.4 \%$ of the total elasmobranch landings of Tamil Nadu while rays contributed 90.3\% and guitarfishes 6.3\%. The major dominant shark species were Carcharhinus falciformis, C. limbatus and
Rhizoprionodon acutus whereas the dominant ray species were Maculabatis (=Himantura) gerrardi, Brevitrygon (=Himantura) imbricata and Gymnura poecilura. and the species belonging to Rhinobatus genus dominated the catch of guitarfishes (CMFRI, 2016).

Some reports on elasmobranch occurrence, fishery biology and population dynamics are available from Tharuvaikulam (Balasubramanian, 2000; Ranjith et al., 2013; Sivadas et al., 2013; Gowthaman et al., 2014). Fish landing data coupled with the spatial component often leads to accurate estimation and interpretation on species distribution and to some extent on the biology, feeding and reproductive pattern (Dineshbabu et al., 2012a; 2015). The use of Geographic Information Systems (GIS) is growing rapidly in many fields of resource management including fisheries and ecosystem management studies (Martin, 2004). However, information on pelagic elasmobranchs (mainly sharks and rays) distribution is lacking as they are found in the open ocean away from or between the boundaries of individual countries. Moreover, these species are caught incidentally as bycatch mainly by fishing vessels targeting tuna and other open ocean fishes. 
An increasing trend in pelagic elasmobranch catch forces fishers to directly target these resources for their meat and their fins (Baum, 2007). Though finning bans have been introduced in many countries, the enforcement measures tend to be lacking and no international catch limits for sharks have been adopted in many countries (Baum, 2007).

Information on the spatiotemporal occurrence of elasmobranchs was particularly lacking from the southern part of Tamil Nadu, especially on the distribution of pelagic elasmobranchs. Hence we attempted to provide insight on the distribution of pelagic elasmobranchs in the Gulf of Mannar Biosphere Reserve (GOMBR) along the south-east coast of India, with an update on the catch composition, species diversity, trends in abundance as well as distribution of species. In addition to the above, the present study also attempts to elaborate geo-tagged major fishing grounds of pelagic elasmobranch resources and the spatio-temporal variations of MGNs fishery of GOMBR based at Thoothukudi.

\section{Materials and methods}

\section{Data collection}

The landings data for the study was collected from the Fisheries Resources Assessment Division of ICARCentral Marine Fisheries Research Institute (ICARCMFRI), Kochi during 2015 and 2016 and was used for studying the catch trend of pelagic elasmobranch fishery along Thoothukudi. The geo-tagged information of fishing operations was collected from pre-identified commercial mechanised gillnetters of Tharuvaikulam coastal village of Thoothukudi District, Tamil Nadu.for a period of two years. The selected gillnetters were equipped with modern scientific gadgets and the data were collected using a structured data collection schedule. The data was not available for the month of May due to the seasonal ban on mechanised fishing vessels along the east coast of India.

\section{Mapping and scaling}

Data on geo-coordinates from the MGNs were used for demarking fishing grounds and for plotting distribution maps. The spatial information collected was used as input for the GIS mapping study and maps were generated using ArcGIS Software. For ease of understanding, the fishing area of GOMBR was classified into seven zones (onedegree grid) as given in Table 1.

The zone-wise clustering was performed using PRIMER v.6 (Plymouth Routines in Multivariate
Table 1. Fishing zones and their extent in GOMBR

\begin{tabular}{lll}
\hline Zone & Latitude $(\mathrm{N})$ & Longitude $(\mathrm{E})$ \\
\hline 1 & $09^{\circ} 00^{\prime}$ to $10^{\circ} 00^{\prime}$ & $79^{\circ} 00^{\prime}$ to $79^{\circ} 45^{\prime}$ \\
2 & $09^{\circ} 00^{\prime}$ to $09^{\circ} 45^{\prime}$ & $78^{\circ} 15^{\prime}$ to $79^{\circ} 00^{\prime}$ \\
3 & $08^{\circ} 15^{\prime}$ to $09^{\circ} 00^{\prime}$ & $79^{\circ} 00^{\prime}$ to $79^{\circ} 30^{\prime}$ \\
4 & $08^{\circ} 00^{\prime}$ to $09^{\circ} 00^{\prime}$ & $78^{\circ} 00^{\prime}$ to $79^{\circ} 00^{\prime}$ \\
5 & $08^{\circ} 00^{\prime}$ to $08^{\circ} 30^{\prime}$ & $77^{\circ} 00^{\prime}$ to $78^{\circ} 00^{\prime}$ \\
6 & $07^{\circ} 00^{\prime}$ to $08^{\circ} 00^{\prime}$ & $78^{\circ} 00^{\prime}$ to $79^{\circ} 00^{\prime}$ \\
7 & $07^{\circ} 00^{\prime}$ to $08^{\circ} 00^{\prime}$ & $77^{\circ} 00^{\prime}$ to $78^{\circ} 00^{\prime}$
\end{tabular}

Ecological Research) software package developed at the Plymouth Marine Laboratory (Clarke and Warwick, 1994; Clarke and Gorley, 2001). Bray-Curtis similarities was performed for the frequency occurrences of geo-coordinates in each zone and multidimensional scaling (MDS) plots were generated for two dimensional representation of similarities in the different zones of GOMBR (Clarke et al., 2008).

\section{Results and discussion}

Fishery

The overall length (OAL) of the selected mechanised gillnetters ranged from 9 to $15 \mathrm{~m}$ with 100 to $120 \mathrm{HP}$ engine and these were engaged in multi-day fishing ranging from 7 to 13 days. Though gillnet is a selective gear, bycatch occurs in MGNs (drift gillnets of mesh size 80-160 cm) of Thoothukudi as the pelagic elasmobranchs are landed as bycatch along with the scombrid fishes like tunas and other large pelagic fish. Balasubramanian (2000) reported that MGNs were operated in the coastal waters at a depth between 30 and $80 \mathrm{~m}$. However the present study showed that an extension of fishing ground even beyond $200 \mathrm{~m}$ depth has occurred due to the modernisation of fishing gear and craft with modern scientific gadgets. During the period of study, the elasmobranch landing of Thoothukudi for 2015 was $87.1 \mathrm{t}$ with a maximum of $17.7 \mathrm{t}$ in July whereas during 2016 it was $107.3 \mathrm{t}$ with a maximum of $39.7 \mathrm{t}$ in the month of February. The average contribution of elasmobranch landing from mechanised gillnetters showed an increasing trend from $1.4 \mathrm{t}$ (2015) to $56.9 \mathrm{t}$ (2016). Compared to 2015, the pelagic elasmobranch landings by gillnetters showed a marginal increase during 2016. The MGN effort steadily increased from 1426 in 2015 to 5045 units in 2016 whereas the average catch per unit effort (CPUE) decreased from $46.8 \mathrm{~kg}$ (2015) to $11.3 \mathrm{~kg}$ (2016). Overall analysis on the elasmobranch catches of Thoothukudi coast revealed that the percentage of elasmobranchs in MGNs decreased to 5.3\% in 2016 from $7.66 \%$ in 2015 whereas the effort increased to 


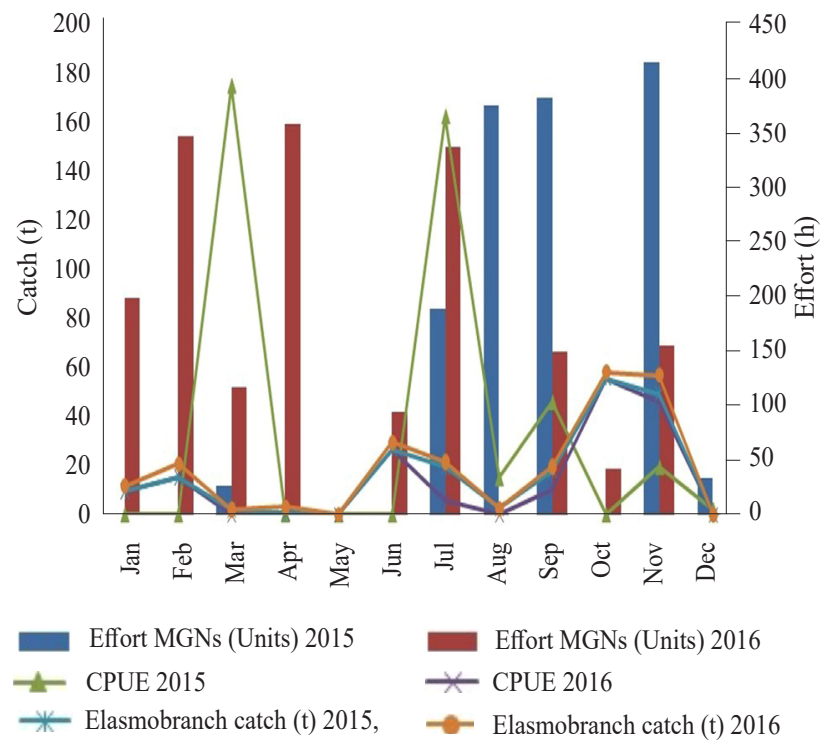

Fig. 1. Monthly catch and effort for elasmobranch landings during the year 2015 and 2016 from MGN of Tharuvaikulam, Thoothukudi

$1.41 \%$ (2016) from $0.4 \%$ (2015). Sharks and rays landed by MGNs accounted for 3.46 and $1.06 \%$ (2015) and 1.19 and $2.15 \%$ (2016) respectively to the total shark and ray landings at Thoothukudi. In the MGN landings at Tharuvaikulam, sharks and rays contributed 24.54 and $74.46 \%$ and 70.02 and $29.98 \%$ respectively during 2015 and 2016 (Fig. 1).

The trend in pelagic elasmobranch catch during the study period was variable and unpredictable as these are

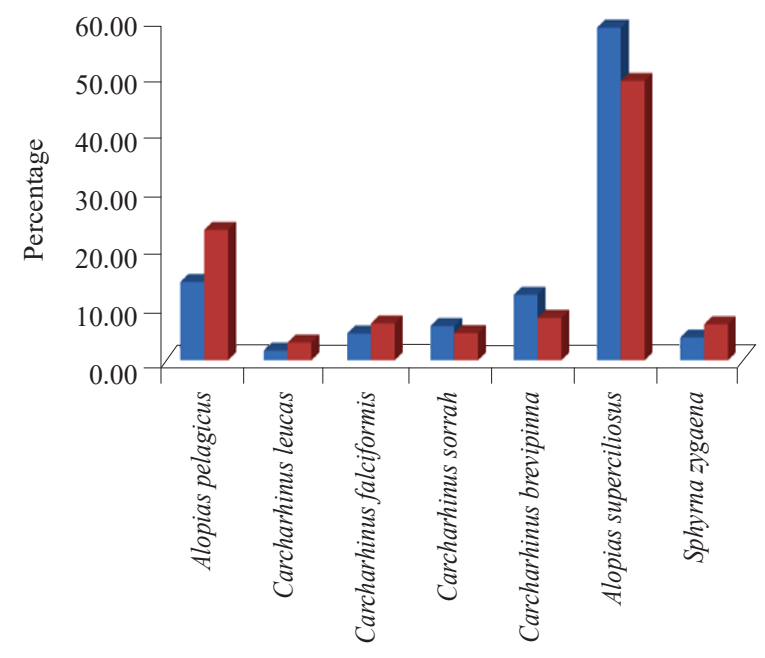

(a) regularly taken as bycatch of drift gillnets targeting the scombrids (mainly tunas) and other large pelagic fishes (sailfish and swordfish). The increase in landings or shift in biomass of elasmobranch species mostly depended on the landings of a few species. In Tharuvaikulam, the increase in landings or shift in biomass of pelagic elasmobranchs were mainly influenced by two major species namely bigeye thresher shark, Alopias superciliosus and spinetail devilray, Mobula japanica. The unpredictable nature of the fishery might be due to the ecological and environmental preference of pelagic elasmobranch species. Behavioural traits can contribute to the frequency of aggregations (Queiroz et al., 2016). Oceanographic features such as frontal regions between different water masses, sharp gradients in temperature or salinity, enhanced primary and secondary productivity support high apex predator diversity and abundance (Worm et al., 2003; Block et al., 2011).

Species composition of pelagic elasmobranchs and IUCN status

In total, 15 species of pelagic elasmobranchs contributed to the catch by MGN of Thoothukudi of which 7 species of sharks and 8 ray species represented the catch whereas no guitarfishes were recorded (Fig. 2a and $b$ ). Among the pelagic elasmobranch species landed from the MGNs of Thoothukudi, 6 species of pelagic sharks and rays are listed in the IUCN red list category (Table 2). Two species of pelagic sharks falls under

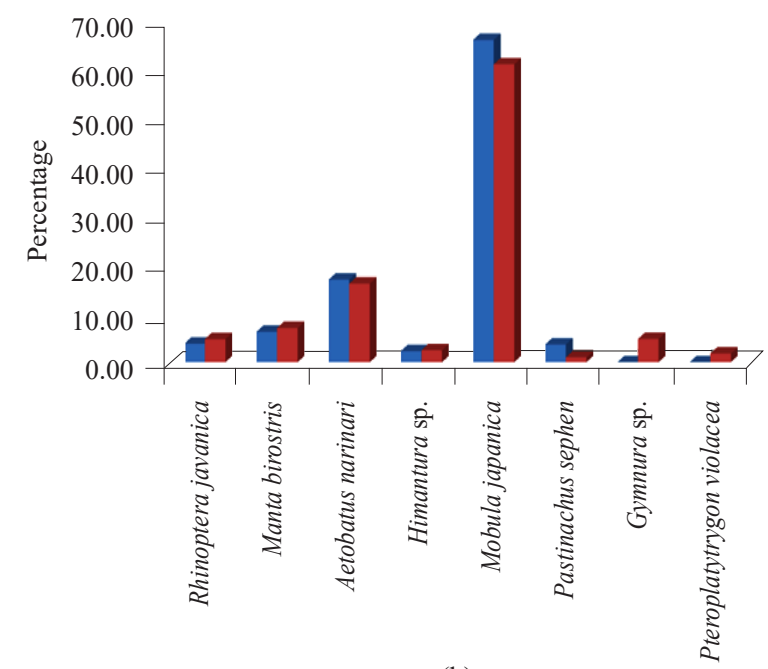

(b)

2015, — 2016

Fig. 2. Monthly variations in species composition of (a) pelagic sharks and (b) pelagic rays from gillnetters operated from Tharuvaikulam, Thoothukudi 
Table 2. IUCN Red List categories of the pelagic elasmobranch species landed in MGNs of Thoothukudi

\begin{tabular}{|c|c|c|c|}
\hline Categories & \multicolumn{2}{|l|}{ Sharks } & Rays \\
\hline $\begin{array}{l}\text { Extinct or Extinct in } \\
\text { the wild }\end{array}$ & \multicolumn{2}{|l|}{-} & - \\
\hline \multicolumn{4}{|l|}{ Threatened ( 2 species) } \\
\hline Critically endangered & Endangered & Vulnerable (2 species) & - \\
\hline \multirow[t]{2}{*}{-} & \multirow[t]{2}{*}{-} & 1. Bigeye thresher, Alopias superciliosus & \\
\hline & & 2. Pelagic thresher, Alopias pelagicus & \\
\hline \multicolumn{4}{|c|}{ Near threatened (3 species) } \\
\hline & \multicolumn{2}{|c|}{ 1. Silky shark, Carcharhinus falciformis } & $\begin{array}{l}\text { 1. Manta ray, Mobula (= Manta) birostris } \\
\text { 2. Spinetail devilray, Mobula japanica }\end{array}$ \\
\hline \multicolumn{4}{|c|}{ Least concern (1 species) } \\
\hline & \multicolumn{2}{|l|}{-} & $\begin{array}{l}\text { 1. Pelagic stingray, } \\
\text { Pteroplatytrygon violacea }\end{array}$ \\
\hline
\end{tabular}

vulnerable category and one species near threatened. Among pelagic rays, 2 species falls under near threatened category and one species is of least concern. In an estimate by Camhi et al. (2009), 32\% of the world's pelagic sharks and rays (20 species) are threatened, which includes $6 \%$ that are endangered and $26 \%$ that are vulnerable. In addition, $24 \%$ are near threatened, $19 \%$ are assessed as of least concern and $25 \%$ are data deficient (Camhi et al., 2009). Pelagic sharks and rays reproduce relatively late and have long life spans with long pregnancies and a few offsprings are regularly taken as incidental "bycatch" by fisheries targeting tuna and swordfish (Dulvy et al., 2007). The United Nations Food and Agriculture Organisation (FAO) adopted the International Plan of Action for Sharks (IPOA-Sharks) in 1999, its provisions are voluntary and hence the implementation of the domestic or international regulation has been slow (Baum, 2007). However, shortage of information limits assessment of these species' status. In India, ICAR-CMFRI framed Guidance on National Plan of Action for Sharks (NPOA-Sharks) in 2015 (Kizhakudan et al., 2015).

\section{Temporal mapping}

The monthly pelagic elasmobranch catch from the fishing grounds by the mechanised gillnetters did not show any steady pattern during the study period. Temporal geospatial mapping revealed that in most seasons the frequency of occurrence of the grounds are more in the Zone 4 followed by Zone 7 (Fig. 3). The clustering of zones is evident from Fig. 4. To pinpoint the yearly overall fishing grounds (Fig. 5a and b) and seasonal fishing grounds (Fig. 6 and 7) of MGNs, geo-referenced pelagic elasmobranch fishing zone map were prepared in ArcGIS platform.

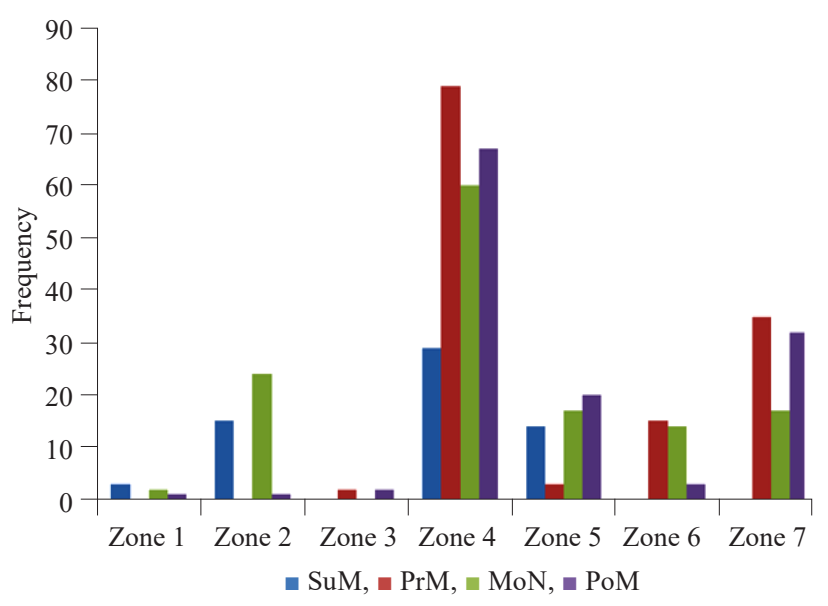

Fig. 3. Seasonal frequency of MGNs in fishing zones along GOMBR.

SuM: Summer; PrM: Pre-monsoon; MoN-Monsoon; PoM: Post-monsoon

Geo-coordinates from the mechanised gillnetters operating from Tharuvaikulam during 2015-2016 revealed that the fishing grounds of MGNs was between $77^{\circ}$ to $80^{\circ} \mathrm{E}$ longitudes and $7^{\circ}$ to $9^{\circ} \mathrm{N}$ latitudes with depth between 50 to $200 \mathrm{~m}$. The results of the geospatial mapping revealed that persistent fishing grounds of MGNs were in Zone 4 , off Thoothukudi between $78^{\circ}$ to $79^{\circ} \mathrm{E}$ and $8^{\circ}$ to $9^{\circ} \mathrm{N}$ followed by Zone 7 , off Kanyakumari between $77^{\circ}$ to $78^{\circ} \mathrm{E}$ and 7 to $8^{\circ} \mathrm{N}$.

Seasonal analysis revealed that pelagic elasmobranch fishing grounds are more during the pre-monsoon season in which the percentage contribution is very high along with the targeted group. While analysing the fishing operation for 2015-2016, most intensive gillnetting operations were 


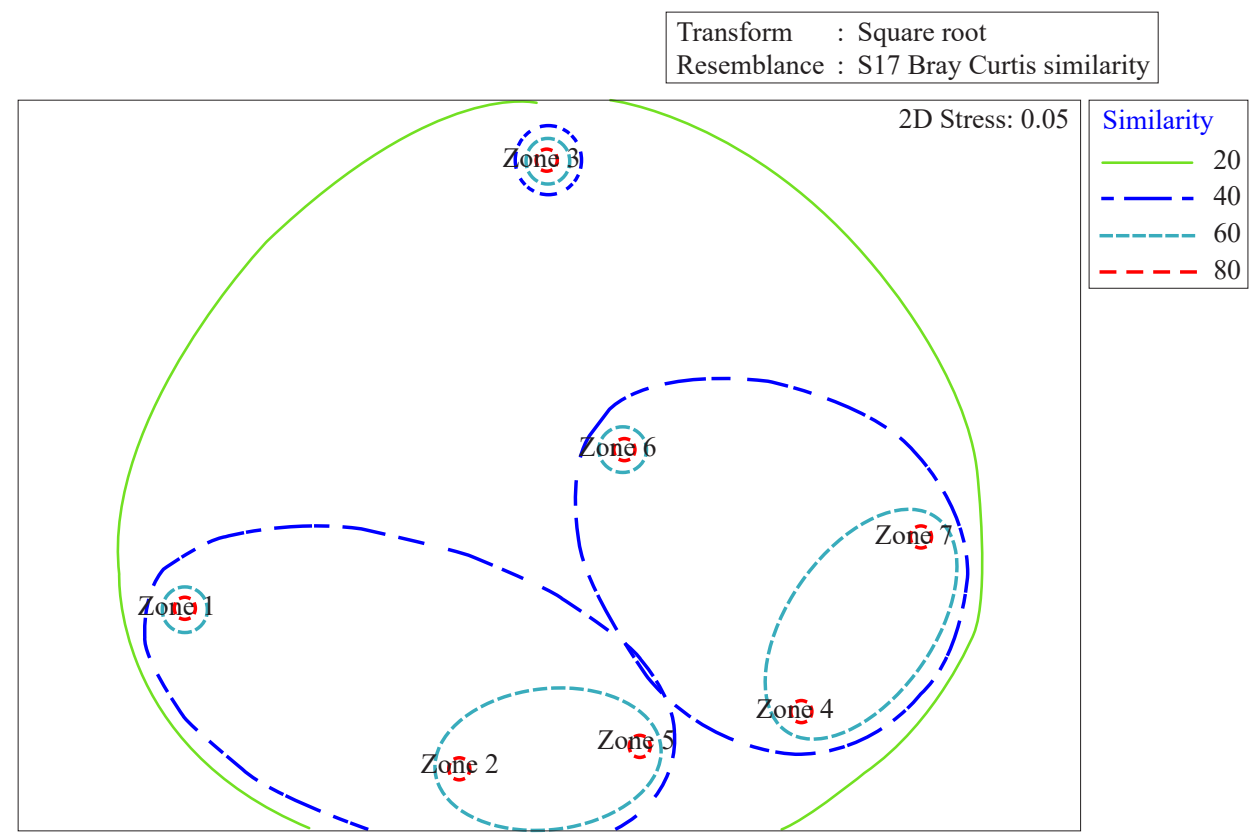

Fig. 4. Clustering of MGN fishing zones along GOMBR

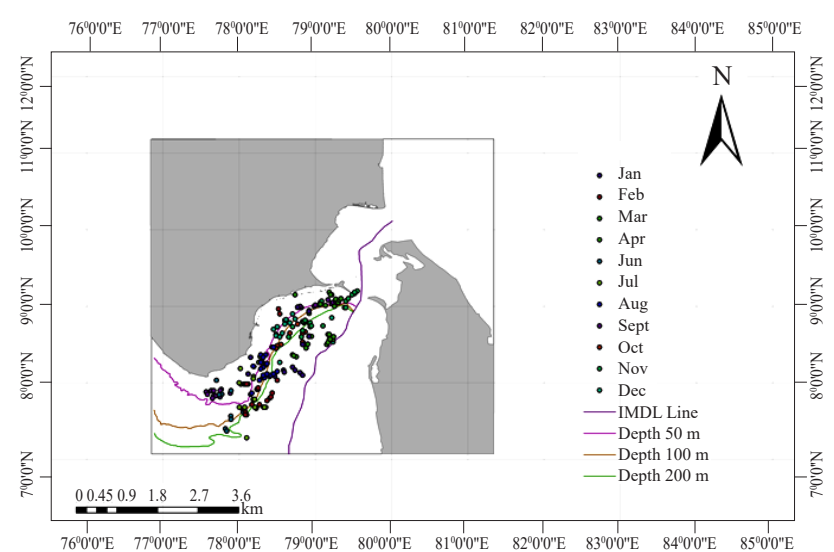

(a)

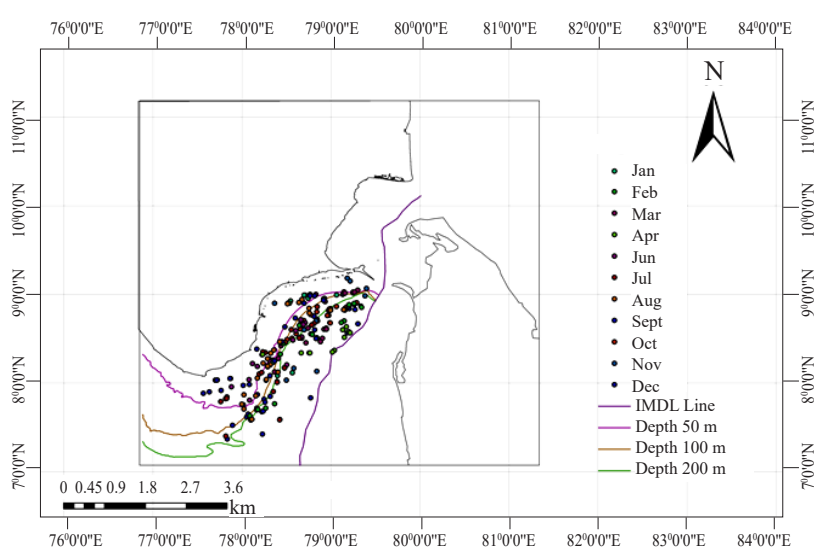

(b)

Fig. 5. Seasonal occurrence of mechanised gillnets along GOMBR for the year (a) 2015 and (b) 2016

observed in fishing grounds at 50 to $100 \mathrm{~m}$ depth off Thoothukudi, Gulf of Mannar, followed by fishing ground at 100 to $200 \mathrm{~m}$ depth off Kanyakumari. The present study revealed that most of the fishing operations are concentrated within the $200 \mathrm{~m}$ depth zone and extension was mainly parallel to the shore, mainly extended in south-west and south-east directions. In inshore waters of Bay of Fundy, Canada, GIS-based mapping on the spatial allocation of fishing intensity has been successfully carried out (Caddy and Carocci, 1999). However, GIS in marine fisheries decision making has been more limited (Isaak and Hubert, 1997; Fisher and Toepfer, 1998). In India, the application of GIS in marine fisheries has been considerably slower but much awareness has developed recently and formed one of the major topics of research during the last decade. ICAR-CMFRI also attempted and demonstrated the utility of GIS in marine fishery resource mapping (Dineshbabu et al., 2012b; 2015; Abdul-Azeez et al., 2016).

Though in the southern part of Tamil Nadu, studies on the spatial mapping of seagrass, coral reef ecosystems and other ecologically sensitive areas of Gulf of Mannar was available (Thangaradjou and Bhatt, 2017), present study was a preliminary attempt to map the fishing grounds for pelagic elasmobranchs in the GOMBR area.

Morfin et al. (2012), analysed the temporal variation in the spatial distribution of key exploited species in the 


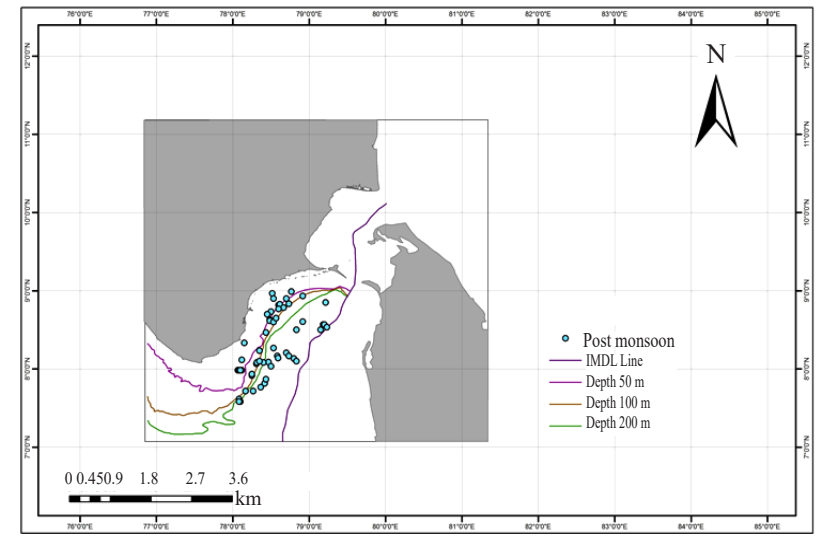

(a)

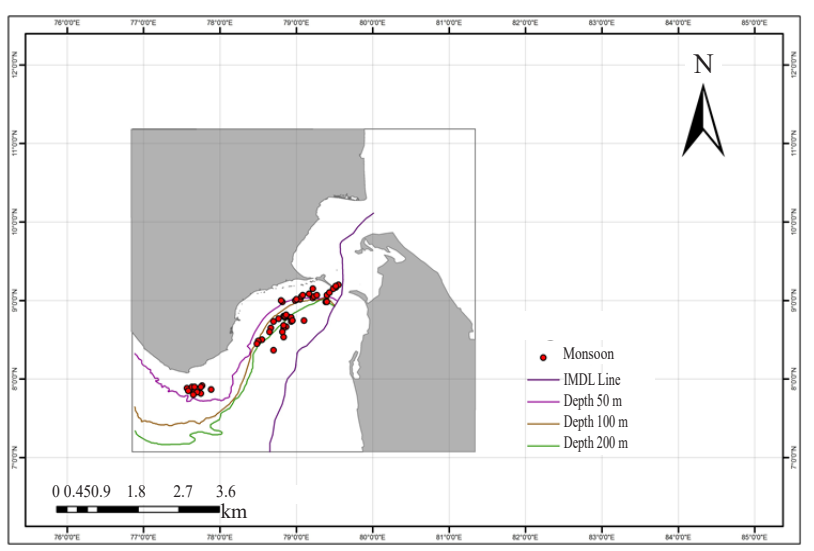

(c)

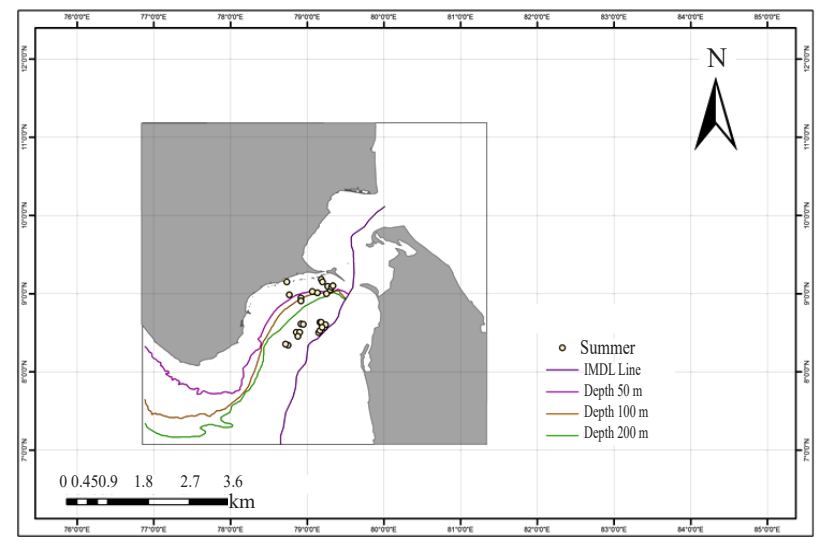

(b)

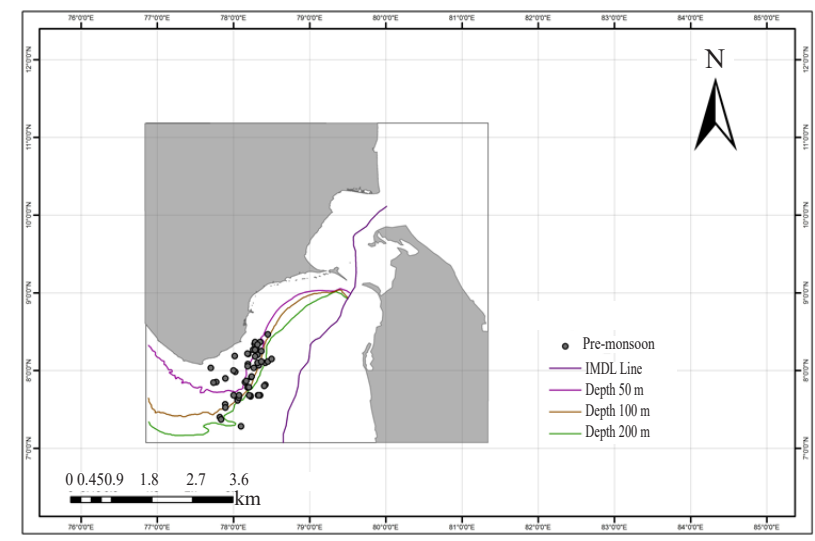

(d)

Fig. 6. Seasonal occurrence of MGNs where elasmobranchs were caught as bycatch along GOMBR, south-east coast of India for the year 2015. (a) Post-monsoon, (b) Summer, (c) Monsoon, (d) Pre-monsoon

Gulf of Lion, north-western Mediterranean Sea and the study revealed that spatial structure of distribution of the 12 key species studied remained same during the sampling period and with varying abundance in adult phase. The current study dealt with 6 key pelagic elasmobranch species (3 sharks and 3 rays) and elucidateds the distribution pattern along GOMBR area. The GIS maps developed from this study may be useful to help understand the repeatability of elasmobranch assemblage and also to know the fishing pressure on the key species along the different fishing areas of GOMBR. In Tamil Nadu, elasmobranchs are commercially important demersal resources and exploitation of elasmobranchs is very high as it is frequently caught as bycatch in the MGNs and on an average catch rate was $36 \mathrm{~kg}$ per unit during the study period.

The repeated presence of certain species of elasmobranchs mostly thresher shark, A. superciliosus and spinetail devilray, M. japanica will help the policy makers to develop species-specific management strategies. The utility of GIS-based elasmobranch resource map can aid in fishing effort restrictions on those fishing grounds in a particular season when the exploitation of elasmobranchs is highest. Similarly, mapping can be carried out for different target species along with the elasmobranch species which is in need of management interventions. Using fishery stock assessment projection model (Thompson and Bell, 1934), sustainable harvest plans can be suggested for scombrids, large pelagic fish and the elasmobranchs caught as bycatch (Dineshbabu and Radhakrishnan, 2009; Dineshbabu et al., 2012a; Moore and Peirce, 2013; Dharmadi and Satria, 2015; Satria and Dharmadi, 2015). Further, long-term studies on the elasmobranch abundance in these fishing grounds will help in identification of critical fishing grounds where seasonal and spatial closure of gillnet fishery can be implemented to improve fishery production in the long run. Similarly, spatio-temporal management of fisheries was suggested by Dunn et al. (2011) in USA to reduce catch of vulnerable finfish and protected species. They also found that such measures 


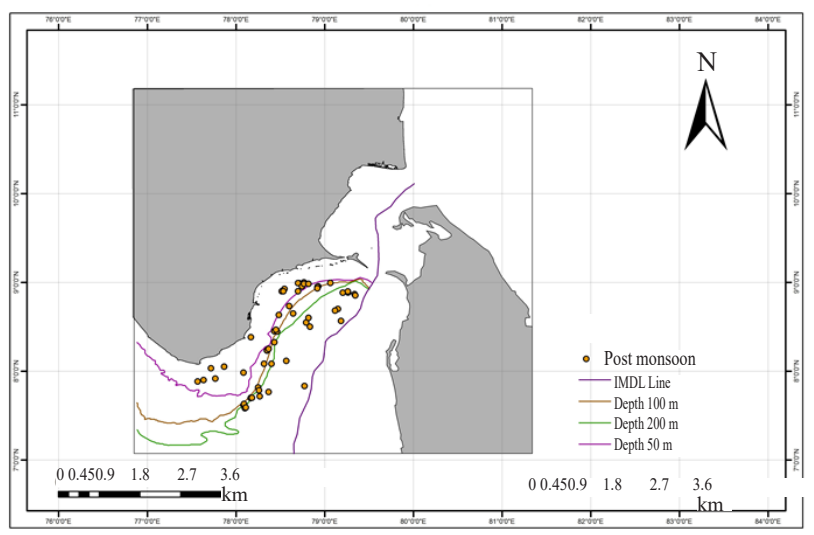

(a)

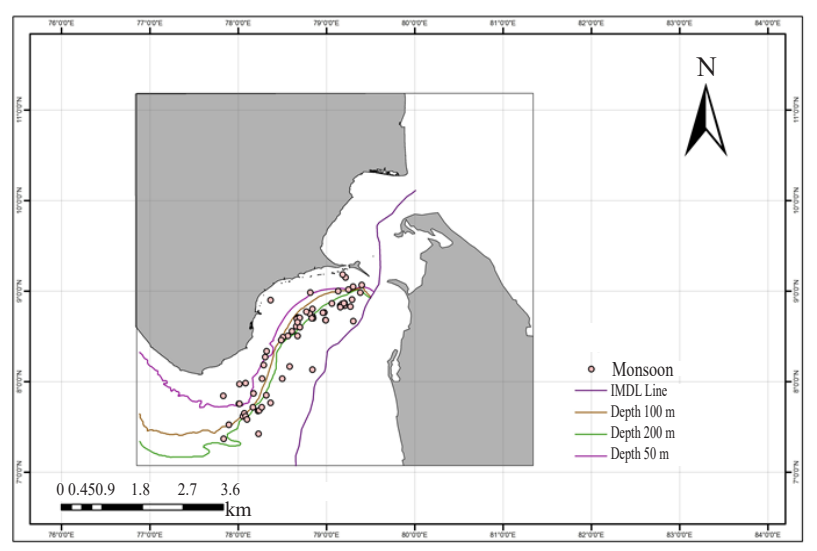

(c)

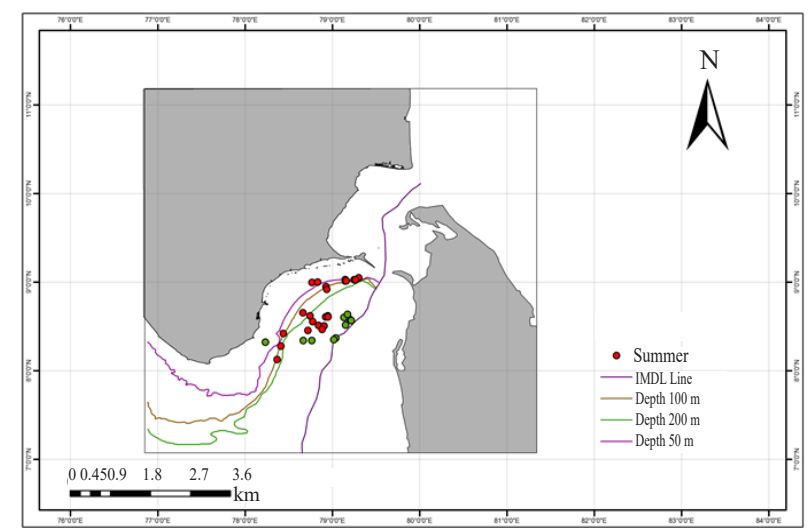

(b)

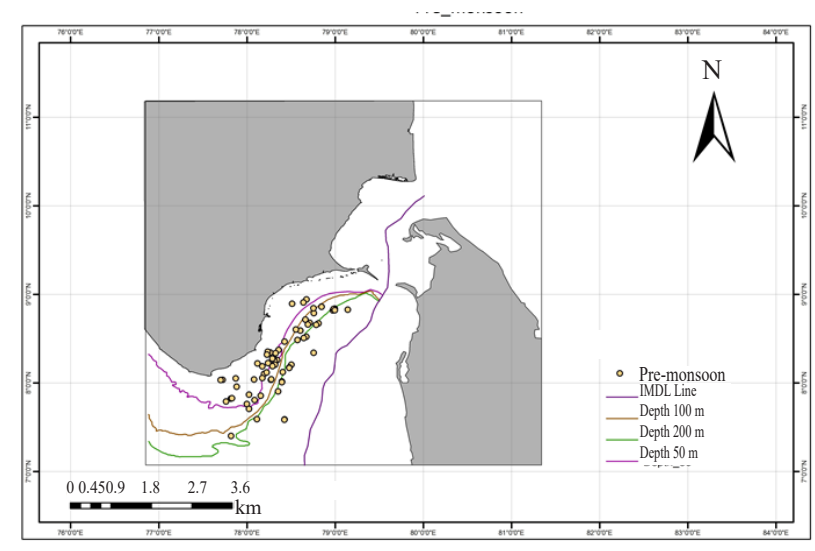

(d)

Fig. 7. Seasonal occurrence of MGNs where elasmobranchs were caught as bycatch along GOMBR, south-east coast of India for the year 2016

are helpful in ecosystem-based management approaches. More fisheries can be managed through multispecies, multi-objective models with availability of the spatial component. Information on spatio-temporal distribution of pelagic elasmobranch resources is a prerequisite for more accurate stock assessments which can aid in the formulation of effective fishery management plans.

\section{Acknowledgements}

The authors are thankful to Dr. P. U. Zacharia, Head, Demersal Fisheries Division and Dr. A. Gopalakrishnan, Director, ICAR-CMFRI, Kochi for the support and encouragement. The co-operation and help provided by the fishing community, especially the boat owners and crews of gillnetter group from Tharuvaikulam, Thoothukudi is acknowledged with gratitude.

\section{Reference}

Abdul Azeez, P., Koya, M., Mathew, K. L., Temkar, G. S. and Khileri, R. A. 2016. GIS based mapping of spatio-temporal distribution pattern of ribbonfish Trichiurus lepturus
(Linnaeus, 1758) along Saurashtra coast, India. Indian J. Fish., 63(4): 10-14. DOI: 10.21077/ijf.2016.63.4.529 12-02.

Balasubramanian, T. S. 2000. Modifications of craft and gear in diversified tuna fishery undertaken at Tharuvaikulam. Gulf of Mannar, India. Mar. Fish. Infor. Serv. $T$ \& E Ser., 164: 19-24.

Baum, J., Clarke, S., Domingo, A. and Ducrocq, M. 2007. Sphyrna lewini. In: IUCN 2012. IUCN Red List of Threatened Species. Version 2012.2.

Block, B. A., Jonsen, I. D., Jorgensen, S. J., Winship, A. J., Shaffer, S. A., Bograd, S. J., Hazen, E. L., Foley, D. G., Breed, G. A., Harrison, A. L. and Ganong, J. E. 2011. Tracking apex marine predator movements in a dynamic ocean. Nature, 475 (7354): 86. doi: 10.1038/nature10082.

Caddy, J. F. and Carocci, F. 1999. The spatial allocation of fishing intensity by port-based inshore fleets: a GIS application. ICES J. Mar. Sci., 56(3): 388-403. DOI: $10.1006 /$ jmsc. 1999.0477 .

Camhi, M. D., Valenti, S. V., Fordham, S. V., Fowler, S. L. and Gibson, C. 2009. The conservation status of pelagic sharks 
and rays. Newbury: IUCN Species Survival Commission Shark Specialist Group, 78 pp.

Clarke, K. R. and Gorley, R. N. 2001. PRIMER v5: User manual, PRIMER-E, Plymouth, UK, 91 pp.

Clarke, K. R. and Warwick, R. M. 1994. Change in marine communities: An approach to statistical analysis and interpretation. $1^{\text {st }}$ edn. Plymouth Marine Laboratory, Plymouth, UK, $144 \mathrm{pp}$

Clarke, K. R., Somerfield, P. J. and Gorley, R. N. 2008. Testing of null hypotheses in exploratory community analyses: similarity profiles and biota-environment linkage. J. Exp. Mar. Bio. Ecol., 366(1-2): 56-69. DOI: 10.1016/j.jembe. 2008.07.009.

CMFRI 2015. CMFRI Annual report 2014-2015. ICAR-Central Marine Fisheries Research Institute, Kochi.

CMFRI 2016. CMFRI Annual report 2015-2016. ICAR-Central Marine Fisheries Research Institute, Kochi.

Dharmadi, F. and Satria, F. 2015. Fisheries management and conservation of sharks in Indonesia. Afr. J Mar. Sci., 37(2): 249-258. doi.org/10.2989/1814232X.2015.1045431.

Dineshbabu, A. P. and Radhakrishnan, E. V. 2009. Trawl fishery of juvenile fishes along Mangalore-Malpe coast of Karnataka and its impact on fish Stock. Asian Fish. Sci., 22(2): 491-500.

Dineshbabu, A. P., Thomas, S. and Dinesh, A. C. 2015. GIS for assessing spatio-temporal variations in trawl bycatch off Mangalore Coast. Fish. Technol., 52: 152-156.

Dineshbabu, A. P., Thomas, S. and Radhakrishnan, E. V. 2012a. Spatio-temporal analysis and impact assessment of trawl bycatch of Karnataka to suggest operation based fishery management options. Indian J. Fish., 59(2): 27-38.

Dineshbabu, A. P., Thomas, S., Radhakrishnan, E. V. and Dinesh, A. C. 2012b. Preliminary experiments on application of participatory GIS in trawl fisheries of Karnataka and its prospects in marine fisheries resource conservation and management. Indian J. Fish., 59(1): 15-22.

Dulvy, N. K., Baum, J. K., Clarke, S., Compagno, L. J. V., Cortes, E., Domingo, A., Fordham, S., Fowler, S., Francis, M. P., Gibson, C., Martinez, J., Musick, J. A., Soldo, A., Stevens, J. D. and Valenti, S. 2007. You can swim but you can't hide: the global status and conservation of oceanic pelagic sharks and rays. Aquatic Conservation, Fisheries management. 1. Conservation and management of sharks. Rome, FAO. 2000. FAO Technical Guidelines for Responsible Fisheries, 4(1): 37pp.

Dunn, D. C., Boustany, A. M. and Halpin, P. N. 2011. Spationtemporal management of fisheries to reduce bycatch and increase fishing selectivity. Fish Fish., 12(1): 110-119. doi.org/10.1111/j.1467-2979.2010.00388.x.

Fisher, W. L. and Toepfer, C. S. 1998. Recent trends in geographic information systems education and fisheries research applications at US universities. Fisheries, 23(5): 10-13. doi.org/10.1577/1548-8446(1998)023<0010:RTIG IS $>2$. $0 . \mathrm{CO} ; 2$.

Gowthaman, A. M., Paulraj Jawahar, V. K. and Venkataramani. 2014. New occurrence of big eye thresher shark Alopias superciliosus Lowe, 1841 in Gulf of Mannar, south-east coast of India. May 2014. Indian J. Geo-Mar. Sci., 43(5): 883-885.

Isaak, D. J. and Hubert, W. A. 1997. Integrating new technologies into fisheries science: the application of geographic information systems. Fisheries, 22(1): 6-10. doi.org/10.1577/1548-8446(1997)022<0006:INTIFS $>2.0$. $\mathrm{CO} ; 2$.

Kizhakudan, S. J., Zacharia, P. U., Thomas, S., Vivekanandan, E. and Muktha, M. 2015. Guidance on national plan of action for sharks in India. CMFRI Marine fisheries policy series No. 2. ICAR-Central Marine Fisheries Research Institute, Kochi, 102 pp.

Martin, K. S. 2004. GIS in marine fisheries science and decision-making. In: Fisher, W. L. and Rahel, F. J. (Eds.), Geographic information systems in fisheries. American Fisheries Society, $276 \mathrm{pp}$.

Mohanraj, G., Rajapackiam, S., Mohan, S., Batcha, H. and Gomathy, S. 2009. Status of elasmobranchs fishery in Chennai, India. Asian Fish. Sci., 22(2): 607-615.

Moore, A. B. M. and Peirce, R. 2013. Composition of elasmobranch landings in Bahrain. Afr. J. Mar. Sci., 35(4): 593-596. DOI: 10.2989/1814232X.2013.866160.

Morfin, M., Fromentin, J. M., Jadaud, A. and Bez, N. 2012. Spatio-temporal patterns of key exploited marine species in the North-western Mediterranean Sea. PloS One, 7(5), p.e37907. DOI: 10.1371/journal.pone.0037907.

Queiroz, N., Humphries, N. E., Mucientes, G., Hammerschlag, N., Lima, F. P., Scales, K. L., Miller, P. I., Sousa, L. L., Seabra, R. and Sims, D. W. 2016. Ocean-wide tracking of pelagic sharks reveals extent of overlap with longline fishing hotspots. Proc. Natl. Acad. Sci., 113(6): 1582-1587. doi.org/10.1073/pnas.1510090113.

Raje, S. G., Mathew, G., Joshi, K. K., Nair, R. J., Mohanraj, G., Srinath, M., Gomathy, S. and Rudramurthy, N. 2002. Elasmobranch fisheries of India - An appraisal. CMFRI Special Publication, 71: 1-76.

Ranjith, L., Sivadas, M., Kannan, K., Kanthan, K. P. and Madan, M. S. 2013. Occurrence of pelagic thresher shark, Alopias pelagicus (Alopiidae: Laminiformes) from the Tuticorin, Gulf of Mannar. Mar. Fish. Infor. Serv. T \& E Ser., 217: 25-26.

Satria, F. and Dharmadi, F. 2015. Pelagic shark fisheries of Indonesia's Eastern Indian Ocean Fisheries Management Region, Afr. J. Mar. Sci., 37(2): 259-265. doi.org/10.2989/ 1814232X.2015.1044908. 
Sivadas, M., Ranjith, L., Sathakathullah, S. M., John James, K. and Suresh Kumar, K. 2013. Pregnant female spinner shark, Carcharhinus brevipinna (Muller \& Henle, 1839) landed at Tharuvaikulam, Tuticorin. Mar. Fish. Infor. Serv. $T \&$ E Ser., 215: 18.

Thangaradjou, T. and Bhatt, J. R. 2017. Status of seagrass ecosystems in India. Ocean Coast. Manag., 159: 7-15. DOI: 10.1016/j.ocecoaman.2017.11.025.
Thompson, W. F. and Bell, H. 1934. Biological statistics of the pacific halibut fishery 2. Effect of changes in intensity upon total yield and yield per unit of gear. Rep. Int. Fish. (Pacific Halibut) Comm., 8: 1-49.

Worm, B., Lotze, H. K. and Myers, R. A. 2003. Predator diversity hotspots in the blue ocean. Proc. Natl. Acad. Sci. USA. 100(17): 9884-9888. doi.org/10.1073/pnas.1333941100. 